УДК 632.51

(C) 2015

Курдюкова О. М., кандидат біологічних наук

Інститут захисту рослин НААН

Жердсва К. О., аспірант

(науковий керівник - кандидат біологічних наук О. М. Курдюкова)

Луганський національний університет імені Тараса Шевченка

\title{
УГРУПУВАННЯ ТА ІНВАЗІЯ CYCLACHAENA XANTHIIFOLIA НА АНТРОПОГЕННО ПОРУШЕНИХ ЕКОТОПАХ
}

\section{Рецензент - доктор сільськогосподарських наук О. О. Іващенко}

\begin{abstract}
Наведено дані багаторічних польових досліджень щзодо особливостей росту ц̌ розвитку рослин Cyclachaena xanthiifolia та видового й кількісного складу видів-супутників у ценопопулячіях різного вікового спектру за різних еколого-фітоценотичних і антропогенних факторів діі. Установлено, щуо видовий та кількісний склад найпоширеніших бур'янів у різновікових угрупуваннях Cyclachaena xanthiifolia cyттєво змінювався, а щчільність популяиій від сходів до плодоношення зменшувалася майже в 10 разів. Найвищою щиільністю схоdis Cyclachaena xanthiifolia (412-321 шm. $\left./ \mathrm{m}^{2}\right)$, рівнем життевості (4) та плодючості (80,5-93,8 тис. ит. 3 рослини) відзначалися иенопопуляиії з невисоким антропогенним впливом на території тваринницької ферми та вздовж берегів річки на пухких вологих трунтах, багатих органічними речовинами.
\end{abstract}

Ключові слова: чорнощуир нетреболистий, ценопопулячія, ріст, розвиток, життєвість, плодючість.

Постановка проблеми. Актуальною проблемою сучасного рільництва є натуралізація в посівах сільськогосподарських культур нових адвентивних видів бур'янів, здатних до успішної конкуренції як 3 наявними бур'янами, так і 3 культурними рослинами. Впровадження адвентивних бур'янів в агрофітоценози призводить до пригнічення росту й розвитку культурних рослин, зменшення врожайності та погіршення його якості [12]. Одним 3 таких шкідливих видів у Степу України стає в останні роки інвазійний дводольний бур'ян північно-американського походження Cyclachaena xanthiifolia (Nutt.) Fressen, 3 родини Айстрові (Asteraceae), занесений до Європи ще у XVIII столітті. [9].

Аналіз основних досліджень і публікацій, у яких започатковано розв'язання проблеми. До недавна вважалося, що Cyclachaena xanthiifolia $\epsilon$ типовим рудеральним бур'яном, який трапляється виключно на смітниках, пустирах, гноєвищах, уздовж доріг, каналів, загорожок, ліній електропередач, біля житла, ферм, складів та інших рудералізо- ваних місцезростаннях $[3,14]$. Однак в останні роки чорнощир нетреболистий став все частіше траплятися на закрайках полів, перелогах, уздовж полезахисних лісосмуг, польових доріг, звідки активно розповсюджується в прилеглі агрофітоценози й низка дослідників почала вважати його за рудеральносегетальний або сегетально-рудеральний вид $[2,7,9]$.

Бур'ян віддає перевагу добре аерованим грунтам, багатих на елементи живлення, на яких утворює значний банк насіння, натуралізується i в кінцевому результаті завдяки швидкій експанciї займає нові території, на яких, зростаючи без відповідного контролю з боку людини, нерідко повністю витісняє 3 рослинних угруповань інші види бур' янів $[1,14]$.

Щорічні втрати валового врожаю зерна сільськогосподарських культур рядкового способу сівби за середнього рівня забур'яненості посівів чорнощиром нетреболистим досягали 20-50 \%, широкорядного - 40-80 \% [5, 11, 13]. У посівах кукурудзи й соняшника відчутне зниження врожайності (до $40 \%$ ) спостерігалося вже за наявності на 1 м $^{2}$ двох рослин чорнощиру нетреболистого. За подальшого збільшення кількості бур'янів у посівах соняш-

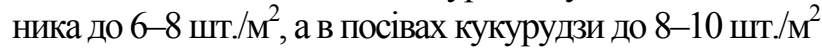
втрачалася понад половина врожаю [10]. Пилок рослин Cyclachaena xanthiifolia відноситься до сильних алергенів. Контакт 3 пилком може викликати розвиток сезонних захворювань алергічної природи, які отримали загальну назву «полінози» [8].

Метою досліджень було визначити особливості росту й розвитку рослин, структури й динаміки ценопопуляцій Cyclachaena xanthiifolia за різних екологофітоценотичних і антропогенних факторів дії з метою розробки ефективних заходів контролю бур'янів.

Завдання досліджень: визначити видовий та кількісний склад найпоширеніших видів-супутників у різновікових ценопопуляціях Cyclachaena xanthiifolia та їх здатність до виживання в ході онтогенетичного розвитку за різного екологофітоценотичного й антропогенного впливу. 


\section{СІЛЬСЬКЕ ГОСПОДАРСТВО. РОСЛИННИЦТВО}

Матеріали і методи досліджень. Польові досліди й спостереження та обліки в них проводили впродовж 2012-2014 pр. в умовах Лівобережного Степу України в 5 ценопопуляціях за чотирьох вікових станів Cyclachaena xanthiifolia. Ценопопуляція № 1 розташовувалася вздовж автомобільної дороги на сухих ущільнених грунтах, насичених мінеральними речовинами; № 2 - поблизу тваринницької ферми на пухких, відносно вологих грунтах, багатих на органічні речовини; № 3 - вздовж залізничних колій на кам’янистощебенюватих грунтах, бідних на мінеральні речовини; № 4 - вздовж вулиць - на чорноземних сильно ущільнених грунтах з середнім забезпеченням поживними речовинами; № 5 - вздовж берегів річки на родючих наносних грунтах, добре забезпечених вологою. Віковий стан: $\mathrm{j}$ (ювенільні) - 2-4 справжніх листка, im (іматурні) 5-12 листків, v (віргінільні) - понад 12 листків, $\mathrm{g}_{1}$ (молоді генеративні) - цвітіння рослин, $\mathrm{g}_{2}$ - формування зерна в Cyclachaena xanthiifolia. За основний показник стійкості рослин у популяціях нами було взято щільність бур'янів у популяціях, ступінь їх розвитку протягом вегетаційного періоду та плодючість. Визначали їх за загальноприйнятими методиками $[4,6]$. Назви рослин наведено за узагальненим списком бур'янів Степу України [9].

Результати досліджень. Cyclachaena xanthiifolia - однорічний ярий ранній бур'ян $з$ пізнім плодоношенням, перші масові сходи якого з'являлися в кінці березня - на початку квітня в ценопопуляціях 1, 2, 4, а найпізніше, в середині квітня, в ценопопуляціях 3,5 .

Проростання насіння розпочиналося в разі прогрівання грунту до $3-6^{\circ} \mathrm{C}$, 3 глибини $2-6 \mathrm{~cm}$. Водночас період від сходів до цвітіння рослин найтривалішим (понад 70 діб) був у популяціях уздовж автомобільних доріг, а найкоротшим (близько 40 діб) - уздовж берегів річки та залізниці. Початок цвітіння рослин чорнощиру нетреболистого розпочинався в кінці травня, а вздовж автодоріг, де рослини на початку вегетації відчували пригнічення росту й розвитку внаслідок значних коливань температури й вологості грунту - в середині червня. Тому генеративна фаза рослин в популяції вздовж автомобільної дороги тривала лише з середини червня до середини липня, тоді як в інших - 3 кінця травня до початку серпня (див. рис.).

У фазу «цвітіння-початок формування насіння» висота рослин чорнощиру нетреболистого в популяціях $1,3,4$, які зазнавали найбільшого антропогенного впливу не перевищувала в середньому 53-104 см, в інших, за меншого антропогенного впливу, - 189-264 см, повітряно-суха маса однієї рослини відповідно 37-53 та 214-273 г, кількість листків на рослині та їх площа 1216 шт. і 6,1-16,2 дм², та 30-45 шт. і 28,8-48,5 дм².

Після проходження генеративної фази розвитку в популяції вздовж залізничних колій спостерігалося інтенсивне старіння, а на серединукінець серпня - відмирання рослин. Насіння, яке утворилося на рослинах цієї популяції, повністю обсипалося й розносилося вітром та іншими шляхами. Пізніше, після плодоношення, на початку вересня, рослини відмирали в популяціях уздовж автомобільної дороги й тваринницької ферми, тоді як уздовж вулиць та берегів річки вони плодоносили до середини-кінця жовтня. Частина насіння (до 20 \%) залишалася на рослинах навіть після їх повного відмирання. Внаслідок значної різниці екологічних умов росту й розвитку рослин у різних ценопопуляціях Cyclachaena xanthiifolia суттєво змінювався й кількісний та видовий склад видів-супутників (табл. 1).

Так, у ценопопуляції № 1 основними видамисупутниками Cyclachaena xanthiifolia були амброзія полинолиста (Ambrosia artemisiifolia L.), будяк акантоподібний (Carduus acanthoides L.), латук дикий (Lactuca serriola L.), гикавка cipa (Berteroa incana (L.) DC.), сокирки східні (Consolida orientalis (J. Gay ex Gren. \& Godr.) Schroedinger), хрінниця смердюча (Lepidium ruderale L.), сухоребрик Ipio (Sisymbrium irio L.) тощо; ценопопуляції № 2 - щириця біла (Amaranthus albus L.), лобода біла (Chenopodium album L.), блекота чорна (Hyoscyamus niger L.), коніза канадська (Conuza canadensis L.), плоскуха звичайна (Echinochloa crusgalli (L.) P. Beauv.), лутига стрілоподібна (Atriplex sagittata Borkh.) тощо; ценопопуляції № 3 - лобода біла (Chenopodium album L.), щириця біла (Amaranthus albus L.), коніза канадська (Conuza canadensis L.), жовтозілля весняне (Senecio vernalis Waldst. \& Kit.), нерівноквітник покрівельний (Anisantha tectorum (L.) Nevski) тощо; ценопопуляції № 4 - амброзія полинолиста (Ambrosia artemisiifolia L.), триреберник незапашний (Tripleurospermum inodorum (L.) Sch. Bip.), спориш звичайний (Polygonum aviculare L.), калачики дрібненькі (Malva pusilla Smith), лутига татарська (Atriplex tatarica L.), лепідотека запашна (Lepidotheca suaveolens (Pursh) Nutt.) тощо; ценопопуляції № 5 - паслін чорний (Solanum nigrum L.), плоскуха звичайна (Echinochloa crusgalli (L.) P. Beauv.), жовтий осот городній (Sonchus oleraceus L.), нетреба ельбінська (Xanthium albinum (Widder) H. Scholz), кінський часник черешковий (Alliaria petiolata (M. Bieb.) Cavara \& Grande), блошниця звичайна (Pulicaria vulgaris Gaertn.), лутига розлога (Atriplex patula L.) тощо. 
СІЛЬСЬКЕ ГОСПОДАРСТВО. РОСЛИННИЦТВО

\begin{tabular}{|c|c|c|c|c|c|c|c|c|c|c|}
\hline \multirow{3}{*}{ Назва бур'янів } & \multicolumn{10}{|c|}{ Місяці, декади } \\
\hline & \multicolumn{2}{|c|}{ квітень } & \multicolumn{2}{|c|}{ травень } & \multicolumn{2}{|c|}{ червень } & \multicolumn{2}{|c|}{ липень } & \multicolumn{2}{|c|}{ серпень } \\
\hline & I $\mathrm{I}$ & III & I II & III & I II & III & I $\mathrm{I}$ & III & I & \\
\hline \multicolumn{11}{|c|}{ Ценопопуляція № 1 вздовж автомобільної дороги } \\
\hline \multicolumn{11}{|l|}{ C. xanthiifolia } \\
\hline \multicolumn{11}{|l|}{ Ambrosia artemisiifolia } \\
\hline \multicolumn{11}{|l|}{ Carduus acanthoides } \\
\hline \multicolumn{11}{|l|}{ Lactuca serriola } \\
\hline \multicolumn{11}{|l|}{ Berteroa incana } \\
\hline \multicolumn{11}{|c|}{ Ценопопуляція № 2 поблизу твариннищької ферми } \\
\hline \multicolumn{11}{|l|}{ C. xanthiifolia } \\
\hline \multicolumn{11}{|l|}{ Amaranthus albus } \\
\hline \multicolumn{11}{|l|}{ Chenopodium album } \\
\hline \multicolumn{11}{|l|}{ Hyoscyamus niger } \\
\hline \multicolumn{11}{|l|}{ Conuza canadensis } \\
\hline \multicolumn{11}{|c|}{ Ценопопуляція № 3 вздовж залізничних колій } \\
\hline \multicolumn{11}{|l|}{ C. xanthiifolia } \\
\hline \multicolumn{11}{|l|}{ Chenopodium album } \\
\hline \multicolumn{11}{|l|}{ Amaranthus albus } \\
\hline \multicolumn{11}{|l|}{ Conuza canadensis } \\
\hline \multicolumn{11}{|l|}{ Senecio vernalis } \\
\hline \multicolumn{11}{|c|}{ Ценопопуляція № 4 вздовж вулиць } \\
\hline \multicolumn{11}{|l|}{ C. xanthiifolia } \\
\hline Ambrosia artemisiifolia & & & & & & & & & & \\
\hline Tripleurospermum inodorus & & & & & & & & & & \\
\hline Polygonum aviculare & & & & & & + & & & & \\
\hline Malva pusilla & & & & & & 曲 & & & & \\
\hline Ценопопу & щія. & 25 & вздов: & 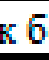 & peri & 8,1 & पारन & & & \\
\hline C. xanthiifolia & & & & & & & & & & \\
\hline Solanum nigrum & & & & & & & & & 册 & \\
\hline Echinochloa crusgalli & & & & & & & 帚 & & & \\
\hline Sonchus oleraceus & & & & & & & & & & \\
\hline Xanthium albinum & & & & & & & & & & \\
\hline
\end{tabular}

ஜ - ювенільні

Рис. Віковий спектр найпоширеніших бур'янів-супутників у різних ценопопуляціях Cyclachaena xanthiifolia 


\section{1. Кількісно-видовий склад найпоширеніших бур'янів-супутників у різних ценопопуляціях Cyclachaena xanthiifolia, 2012-2014 pp.}

\begin{tabular}{|c|c|c|c|c|}
\hline \multirow{2}{*}{$\begin{array}{l}\text { Видовий склад } \\
\text { бур'янів }\end{array}$} & \multicolumn{4}{|c|}{$\begin{array}{l}\text { Кількість бур'янів у ценопопуляціях за різного вікового стану } \\
\text { Cyclachaena xanthiifolia, шт./м²; }\end{array}$} \\
\hline & j (ювенільні) & im (іматурні) & v (віргінільні) & $\begin{array}{c}\mathrm{g}_{1} \text { (молоді } \\
\text { генеративні) }\end{array}$ \\
\hline \multicolumn{5}{|c|}{ Ценопопуляція № 1 уздовж автомобільної дороги } \\
\hline Cyclachaena xanthiifolia & 306,8 & 201,4 & 61,1 & 13,5 \\
\hline Ambrosia artemisiifolia & 45,7 & 21,3 & 9,3 & 2,3 \\
\hline Carduus acanthoides & 2,9 & 2,5 & 2,2 & 2,8 \\
\hline Lactuca serriola & 1,9 & 2,6 & 2,0 & 2,0 \\
\hline Berteroa incana & 1,8 & 2,3 & 1,8 & 2,9 \\
\hline Інші & 4,1 & 5,4 & 5,6 & 5,8 \\
\hline \multicolumn{5}{|c|}{ Ценопопуляція № 2 поблизу тваринницької ферми } \\
\hline Cyclachaena xanthiifolia & 412,6 & 291,8 & 68,6 & 41,9 \\
\hline Amaranthus albus & 33,9 & 20,9 & 11 & 11,4 \\
\hline Chenopodium album & 2,4 & 1,9 & 2,2 & 2,9 \\
\hline Hyoscyamus niger & 2,4 & 2,1 & 2,5 & 2,6 \\
\hline Conuza canadensis & 1,7 & 1,9 & 1,9 & 2,9 \\
\hline Інші & 6,2 & 5,1 & 5,5 & 4,7 \\
\hline \multicolumn{5}{|c|}{ Ценопопуляція № 3 вздовж залізничних колій } \\
\hline Cyclachaena xanthiifolia & 216,3 & 112,3 & 41,1 & 12,3 \\
\hline Chenopodium album & 33,2 & 13,7 & 9,9 & 5,3 \\
\hline Amaranthus albus & 1,9 & 2,5 & 2,3 & 2,6 \\
\hline Conuza canadensis & 2,2 & 2,2 & 2,0 & 2,0 \\
\hline Senecio vernalis & 1,9 & 2,5 & 1,9 & 2,5 \\
\hline Інші & 6,0 & 5,4 & 6,0 & 5,6 \\
\hline \multicolumn{5}{|c|}{ Ценопопуляція № 4 вздовж вулиць } \\
\hline Cyclachaena xanthiifolia & 247,7 & 174,4 & 60,2 & 18,6 \\
\hline Ambrosia artemisiifolia & 30,1 & 16,7 & 13,2 & 7,4 \\
\hline Tripleurospermum inodorum & 1,8 & 2,7 & 2,1 & 2,7 \\
\hline Polygonum aviculare & 2,3 & 2,5 & 2,3 & 2,4 \\
\hline Malva pusilla & 2,0 & 2,3 & 2,3 & 2,7 \\
\hline Інші & 4,4 & 6,1 & 6,4 & 5,7 \\
\hline \multicolumn{5}{|c|}{ Ценопопуляція № 5 уздовж берегів річки } \\
\hline Cyclachaena xanthiifolia & 321,4 & 200,4 & 60,7 & 41,1 \\
\hline Solanum nigrum & 27,3 & 24,6 & 15,8 & 11,1 \\
\hline Echinochloa crusgalli & 2,1 & 2,5 & 2,3 & 2,5 \\
\hline Sonchus oleraceus & 1,7 & 2,3 & 2,5 & 2,0 \\
\hline Xanthium albinum & 2,5 & 2,6 & 1,8 & 2,7 \\
\hline Інші & 4,8 & 5,5 & 5,2 & 5,0 \\
\hline
\end{tabular}

\section{2. Плодючість рослин чорнощиру нетреболистого в різних ценопопуляціях, 2012-2014 pр.}

Кількість насіння $з 1$ рослини, тис. шт.

Ценопопуляції

\begin{tabular}{|c|c|c|c|c|c|}
\hline насіння & 1 & 2 & 3 & 4 & 5 \\
\hline Мінімальна & 91 & 2344 & 26 & 51 & 1860 \\
\hline Середня & 8297 & 93802 & 5000 & 37994 & 80516 \\
\hline Максимальна & 49118 & 129026 & 7884 & 54002 & 105108 \\
\hline Абсолютно максимальна & 71316 & 156173 & 11156 & 97060 & 133774 \\
\hline
\end{tabular}




\section{СІЛЬСЬКЕ ГОСПОДАРСТВО. РОСЛИННИЦТВО}

Щільність рослин Cyclachaena xanthiifolia ювенільного стану була найвищою у ценопопуляціях 2 і 5 і складала відповідно 412,6 і 321,4 шт./м², або 89,9-89,3 \% від загальної кількості бур'янів, дещо меншою вона була в популяціях 1, 3 і 4 - досягаючи 306,8-216,3 шт./м² або $75,0-85,9 \%$ відповідно. За іматурного стану розвитку частка Cyclachaena в усіх ценопопуляціях досягала максимуму $-81,0-90,1 \%$, тоді як у віргінільному щільність іiі в ценопопуляціях, розташованих уздовж автомобільної дороги та тваринницької ферми, не перевищувала 74,5-74,8 \%, уздовж вулиць та берегів річки - 68,7-69,6\%, залізничних колій - 65,0 \%, а від генеративного стану й до кінця вегетації в популяціях на території тваринницької ферми та вздовж берегів річки, де склалися найкращі умови живлення та водного режиму - 63,1-63,8 \%, а в інших популяціях 3 гіршими умовами $-41,6-47,1 \%$.

Природне зменшення кількості рослин в угрупуваннях від ювенільного вікового стану до відмирання рослини Cyclachaena xanthiifolia пояснюється внутрішньовидовою конкуренцією фітоценозів за фактори життя та генетивно закладеним рівнем щільності, який за наведених екологічних умов забезпечував найвищі показники життєвості та максимальну репродуктивну здатність кожної рослини й популяції загалом.

Так, середня насіннєва продуктивність однієї рослини чорнощиру нетреболистого в популяціях № 2 та 5, розташованих на території тваринницької ферми та вздовж берегів річки, за оптимальних екологічних умов перевищувала 80 93 тис. шт., тоді як за погіршених умов росту й розвитку рослин в популяції № 4 вона зменшу-

\section{БІБЛІОГРАФІЯ}

1. Абрамова Л. М. Современное распространение Cyclachaena xanthiifolia (Nutt.) Fresen в Республике Башкортостан / Л. М. Абрамова, С. В. Нурмиева : материалы междунар. науч.практ. конф. [«Ботанические сады в XXI веке: сохранение биоразнообразия, стратегии развития и инновационные решения»]. - Белгород, 2009. C. $141-142$.

2. Бур'яни України : визначник-довідник / [Барбарич А. І., Вісюліна О. Д., Воробйов М. Є. та ін.] - К. : Наукова думка, 1970. - 507 с.

3. Голицын С. В. К вопросу об антропохорных миграциях растений / С. В. Голицын // Советская ботаника. - Л., 1947. - №6. - С. 3 -5.

4. Доспехов Б. А. Методика полевого опыта / Б. А. Доспехов. - М. : Агропромиздат, 1985. - 351 с.

5. Драніщев М. I. Чорнощир нетреболистий. Розповсюдження і засоби боротьби з ним в умо- валася в 2,1-2,5 разів, а в популяціях 1 і 3, які найбільшою мірою зазнавали негативного антропогенного впливу - в 11-16 разів і не перевищувала 5,0-8,2 тис. шт. (табл. 2).

Аналогічним чином змінювалася в популяціях і максимальна плодючість бур'янів, досягаючи 105,1-129,0 тис. шт. 3 рослини. Абсолютно максимальну насіннєву продуктивність однієї рослини чорнощиру нетреболистого - близько 156,2 тис. шт., було зафіксовано в популяції на території тваринницької ферми.

Висновок. Таким чином, в умовах Лівобережного Степу України перші сходи Cyclachaena xanthiifolia 3'являються в кінці березня - на початку квітня в популяціях, розташованих уздовж автомобільних доріг і вулиць, територіях тваринницьких ферм, а раннє плодоношення й відмирання рослин в середині липня - у популяціях залізничних колій. Вегетація й плодоношення рослин, що трапляються вздовж вулиць і берегів річок, триває до кінця жовтня. Видовий склад бур'янів-супутників різних ценопопуляцій Cyclachaena xanthiifolia включає низку небезпечних для рільництва видів, зокрема Ambrosia artemisiifolia, Chenopodium album, Amaranthus albus, Conuza canadensis тощо, частка яких від сходів до плодоношення чорнощиру збільшується. Найвищою щільністю сходів чорнощиру нетреболистого (412-321 шт./м²), рівнем життєвості (4) та плодючості $(80,5-93,8$ тис. шт. 3 рослини) відзначаються ценопопуляції з невисоким антропогенним впливом на території тваринницької ферми та вздовж берегів річки на пухких вологих грунтах, багатих органічними речовинами.

вах Донбасу / М. I. Драніщев, I. I. Малихін // Проблеми бур'янів i шляхи зниження забур'янених орних земель. - К. : Колобіг, 2004. C. $48-52$.

6. Ермакова И. М. Подходы к изучению ценопопуляций и консорций / И. М. Ермакова, Л. Е. Гатцук, М. С. Чугаркина. - М. : МГПИ, 1987. $-79 \mathrm{c}$.

7. Конопля M. I. Чорнощир нетреболистий: морфологічні особливості та заходи контролювання в північній Степовій зоні України / М. І. Конопля, О. М. Курдюкова, Н. О. Мельник // Карантин і захист рослин. - 2010. - №3. - С. 8-9.

8. Видовий склад та пилкоутворююча здатність алергенних видів рослин на Сході України / [Конопля М. І., Корольова Т. Г., Ботарчуков О. В., Бурега А. С.] // Вісник ЛДПУ імені Тараса Шевченка. - 2000. - №3 (3). - С. 29-33. 
9. Курдюкова О. М. Бур'яни Степів України / О. М. Курдюкова, М. І. Конопля. - Луганськ : вид-во «Елтон-2», 2012. - 318 с.

10. Курдюкова О. М. Шкідливість чорнощиру нетреболистого в посівах кукурудзи і соняшнику / О. М. Курдюкова, С. В. Маслійов, К. О. Жердева // Карантин і захист рослин. - 2014. - №5. - С. 3-4.

11. Манжос C. В. Обгрунтування заходів боротьби 3 чорнощиром нетреболистим та іншими бур'янами на необроблюваних землях господарств Лівобережного Лісостепу України : дис. кандидата с.-г. наук : 06.01.01 «Загальне земле- робство» / С. В. Манжос. - Полтавська державна аграрна академія. - Полтава, 2001. - $182 \mathrm{c.}$

12. Мар 'юшкіна В. Я. Причини та наслідки фітозабруднення в Україні / В. Я. Мар'юшкіна // Посібник українського хлібороба. - 2008. C. $153-156$.

13. Матюха Л. П. Бур'яни-алергени / Л. П. Матюха, В. Л. Матюха, В. В. Рябоволенко // Захист рослин. - 2003. - №6. - С. 14-17.

14. Протопова В. В. Рослини-мандрівники / В. В. Протопова. - К. : Радянська школа, 1989. C. $70-74$. 